\title{
Evaluation of extraction methods for obtaining high-quality RNA from sweet potato
}

\author{
R.C. Gonçalves ${ }^{1}$, M.M. Daude ${ }^{1}$, M.R. de Souza ${ }^{1,3}$, M.B.F. Moraes ${ }^{1}$, \\ R.O. Moreira ${ }^{2}$, M.A. da Silveira ${ }^{3}$, S.A. Ságio ${ }^{1,3}$ and H.G. Barreto ${ }^{1}$ \\ ${ }^{1}$ Laboratório de Análises Moleculares, Departamento de Ciências da Vida, \\ Universidade Federal do Tocantins, Palmas, TO, Brasil \\ ${ }^{2}$ Laboratório de Fisiologia Molecular de Plantas, Departamento de Biologia, \\ Universidade Federal de Lavras, Lavras, MG, Brasil \\ ${ }^{3}$ Programa de Pós-graduação em Agroenergia Digital, Universidade Federal do \\ Tocantins, Palmas, TO, Brasil
}

Corresponding author: H.G. Barreto

E-mail: horllys@uft.edu.br

Genet. Mol. Res. 20 (4): gmr18939

Received July 13, 2021

Accepted November 25, 2021

Published December 28, 2021

DOI http://dx.doi.org/10.4238/gmr18939

ABSTRACT. Considering the great economic and social importance of sweet potato and the few transcriptome studies carried out on this species so far, which can potentially lead to significant improvements in its production system at both productivity and quality levels, this study aimed to determine the most suitable methodology for extracting highquality RNA from sweet potato's tuberous roots, branches, and leaves. The experiment was composed of three biological replicates, each one comprising three plants. $100 \mathrm{mg}$ of ground tissue was used for isolating RNA through the CTAB and TRIzol methods, while $160 \mathrm{mg}$ was used for the Hot Phenol Acid method. From the three tested protocols, all of them enabled the isolation of RNA at quantities above $250 \mathrm{ng} / \mu \mathrm{L}$ for the three different tissues, which is the minimal quantity required for conducting molecular assays such as RT-qPCR. However, in terms of RNA quality, evaluated through the $\mathrm{A}_{260} / \mathrm{A}_{280}$ and $\mathrm{A}_{260} / \mathrm{A}_{230}$ ratios, only the Hot Phenol Acid and CTAB methods generated satisfactory results, displaying values from 1.8 to 2.2. To conclude, the hot acid phenol and CTAB methods, not commonly used for transcriptional studies in sweet potato, are excellent choices for the RNA extraction from different sweet potato tissues. 
Key words: Ipomoea batatas; Gene expression; Transcriptome; RT-qPCR

\section{INTRODUCTION}

Sweet potato is an important crop that is cultivated in several countries, since its tuberous roots are an excellent source of carbohydrates, vitamins, and minerals (Pessu et al., 2020), in addition to being used in the production of nutraceuticals (Zhang et al., 2017) and bioethanol (Rizzolo et al., 2021). More than 91 million tons of sweet potato is produced worldwide, with China, the world's largest sweet potato producer, being responsible for 57 $\%$ of this total (FAO, 2021). The Brazilian sweet potato production, which comes from 29 registered cultivars, has reached 350,512 tons (MAPA, 2019). Considering its adaptation to diverse edaphoclimatic conditions, the production levels and cultivation area of sweet potato have significantly increased throughout the Brazilian territory. According to the Brazilian Institute of Geography and Statistics (IBGE, 2019), the Northeast, South and Southeast regions of Brazil are the main production areas of this crop.

Considering the economic importance of sweet potatoes, various breeding studies, mainly performed through conventional methods, such as the selection of superior genotypes, have been carried out (Azevedo et al., 2014). However, the selection process and the improvements in the crop take long periods of time to be achieved, and require a high number of individuals and adequate reproductive systems, considering that sweet potato is a hexaploid species $(2 \mathrm{n}=6 \mathrm{x}=90$ chromosomes) (Srisuwan et al., 2006). Thus, biotechnology acts as complementary tool for the classical plant breeding methods, allowing the development of tolerant genotypes for different pathogens and diseases in several species, in addition to enabling the generation of plants that can better deal with environmental variations, optimizing their physiological responses to their cultivation conditions and directly improving the production system, from quality to productivity (Anwar and Kim, 2020; Basso et al., 2020). Gene expression analysis is of fundamental importance in these studies and it can be performed through different techniques, among which Reverse Transcription - quantitative Real Time PCR (RT-qPCR) stands out, considering its sensitivity, reproducibility, and precision (Derveaux et al., 2010). However, to perform studies using this technique, several parameters should be followed in order to get reliable results, such as using high-quality RNA, displaying good integrity levels, choosing the right method for the cDNA synthesis, good amplification efficiencies of the primers, and appropriate reference genes (Bustin et al., 2009; Derveaux et al., 2010). Among the previous mentioned parameters, high-quality RNA is the first step for conducting transcriptional studies.

Several studies have been performed in different plant species, such as citrus (Huma et al., 2020), brassica (Siles et al., 2020), cassava (Behnam et al., 2019), Phaseolus vulgaris (Acosta-Maspons et al., 2019), Elaeis guineensis (Ong et al., 2019), and coffee (Paula et al., 2012; Huded et al., 2018) aiming to establish the best method for obtaining high-quality RNA. Plant tissues may have compounds, such as polysaccharides and polyphenols, that can negatively interfere in isolating high-quality nucleic acids (Badai et al., 2020), turning this process many times unique for each plant tissue.

Sweet potato shows high levels of polysaccharides (Guo et al., 2017) and polyphenols (Wang et al., 2018), and different methods for isolating high-quality RNA have been tested in this species, including TRIzol (Meng et al., 2018; Ma et al., 2020) and 
commercial kits (Guoliang et al., 2020). However, so far, there are no studies comparing the efficiency of these different methods.

Thus, considering the importance of transcriptional studies and the difficulties in isolating high-quality RNA, as well as, the absence of studies comparing RNA isolation methods in sweet potato, this study aimed to determine the best method for isolating highquality RNA from three different sweet potato tissues: tuberous roots, branches, and leaves.

\section{MATERIAL AND METHODS}

\section{Plant material}

In order to determine the best RNA isolation method for sweet potato tissues, an experiment was carried out at the research station of the Palmas University Campus, of the Federal University of Tocantins (Latitude: 10¹0'40" S; Longitude: 48 $21^{\prime} 43^{\prime \prime O}$; Altitude: $220 \mathrm{~m}$ ), and all molecular analysis were performed in the Laboratory of Molecular Analysis (LAM/Human-Health-UFT). The experiment was conducted using five-months-old sweet potato (Ipomoea batatas cv. Duda) plants, using three biological replicates, each one comprising three plants. Tuberous roots, branches, and leaves (young and fully expanded) from the three plants of each biological replicate were collected and immediately frozen in liquid nitrogen and then stored at $-80^{\circ} \mathrm{C}$ until RNA extraction.

\section{RNA extraction methods}

In order to determine the RNA isolation methods to be tested for sweet potato tissues, a search was first carried out on the Web of Science (https://www.webofknowledge.com) and Scopus (https://wwwscopus.ez6.periodicos.capes.gov.br/) databases, using the key-words gene expression, RNA, protocols, RT-qPCR, and sweet potato / Ipomoea batatas. Three different methods were chosen: hot acid phenol, CTAB (Cetyltrimethylammonium Bromide) (Chang et al., 1993), and TRIzol (Invitrogen).

\section{Hot acid phenol method}

The RNA extraction through the hot phenol acid methods was performed according to the protocol described by De Souza et al. (2021), with the following modifications: 160 mg of plant material, grinded in liquid nitrogen, was added to each microtube and $650 \mu \mathrm{L}$ of acid Phenol were added, followed by homogenization. Then, $650 \mu \mathrm{L}$ of TES (10 mM Tris$\mathrm{HCl} \mathrm{pH} \mathrm{7.5,} 10 \mathrm{mM}$ EDTA and 0.5\% SDS) were added and samples were homogenized. After incubating the samples on ice for five min and then on a dry bath incubator for one hour at $60{ }^{\circ} \mathrm{C}$, with sample homogenization at every $10 \mathrm{~min}$, samples were centrifuged for $10 \mathrm{~min}$ at $14,000 \mathrm{rpm}$ and $4{ }^{\circ} \mathrm{C}$. The supernatant $(600 \mu \mathrm{L})$ was transferred to a new microtube and $600 \mu \mathrm{L}$ of Acid Phenol was added, followed by homogenization. Samples were once again incubated on ice for five min and then centrifuged $(10 \mathrm{~min} / 14.000 \mathrm{rpm} / 4$ ${ }^{\circ} \mathrm{C}$ ). After centrifugation $300 \mu \mathrm{L}$ of the supernatant were transferred to a new microtube (for tuberous roots, the supernatant of two tubes from each replicate were added to a single tube in order to increase the RNA amount to be extracted) for RNA precipitation, which was 
carried out by the addition of $600 \mu \mathrm{L}$ and $350 \mu \mathrm{L}$ of isopropanol to the tuberous roots and other tissues, respectively. Samples were incubated for one hour at $-20^{\circ} \mathrm{C}$ and then centrifuged $(30$ $\min / 14.000 \mathrm{rpm} / 4{ }^{\circ} \mathrm{C}$ ), with the supernatant being discarded and the RNA pellet washed with $700 \mu \mathrm{L}$ of cold $70 \%$ ethanol, followed by a last centrifugation step $\left(8 \mathrm{~min} / 14.000 \mathrm{rpm} / 4^{\circ} \mathrm{C}\right)$. Finally, the RNA pellet was resuspended in $20 \mu \mathrm{L}$ of nuclease-free water and samples were stored at $-80{ }^{\circ} \mathrm{C}$.

\title{
CTAB method
}

RNA extraction through the $\mathrm{CTAB}$ method was carried out according to the protocol described by Chang et al. (1993), adapted to microtubes and with minor modifications. $450 \mu \mathrm{L}$ of the extraction buffer [ $2 \%(\mathrm{w} / \mathrm{v})$ CTAB (Cethyltrimethylammonium Bromide), $2 \%(\mathrm{w} / \mathrm{v})$ PVP, $100 \mathrm{mM}$ of Tris-HCL, $25 \mathrm{mM}$ of EDTA, $20 \mathrm{mM}$ of NaCl], $450 \mu \mathrm{L}$ of TES (10 Mm de TRIS$\mathrm{HCL} \mathrm{Ph} \mathrm{7,5,} 10 \mathrm{mM}$ de EDTA e $0,5 \%$ SDS), and $100 \mu \mathrm{L}$ of $\beta$-mercaptoethanol were first added to $100 \mathrm{mg}$ of ground material. After sample homogenization, samples were incubated for one hour at $65{ }^{\circ} \mathrm{C}$ on a dry bath incubator, with sample homogenization at every $10 \mathrm{~min}$. Then, samples were centrifuged for $10 \mathrm{~min}$ at $11,000 \mathrm{rpm}$ and $4{ }^{\circ} \mathrm{C}$, with $800 \mu \mathrm{L}$ of the supernatant being then transferred to microtubes containing $800 \mu \mathrm{L}$ of chloroform. After homogenizing the samples, samples were again centrifuged $\left(10 \mathrm{~min} / 11.000 \mathrm{rpm} / 4^{\circ} \mathrm{C}\right)$, and $400 \mu \mathrm{L}$ of the supernatant then were added to new microtubes containing $400 \mu \mathrm{L}$ of isopropanol for RNA precipitation, which occurred through the incubation of the samples for $60 \mathrm{~min}$ at $-20{ }^{\circ} \mathrm{C}$. The RNA pellet was generated after centrifuging the samples for $30 \mathrm{~min}$ at $13,800 \mathrm{rpm}$ and $4{ }^{\circ} \mathrm{C}$, the supernatant was discarded, and the pellet washed with $800 \mu \mathrm{L}$ of cold $75 \%$ ethanol. After centrifuging the samples for $8 \mathrm{~min}$ at 13,800 and $4{ }^{\circ} \mathrm{C}$, ethanol was discarded and the pellets dried for approximately $5 \mathrm{~min}$ on an oven at $37{ }^{\circ} \mathrm{C}$, being finally resuspended in nuclease-free water and then stored at $-80^{\circ} \mathrm{C}$.

\section{TRIzol method}

\author{
RNA extraction using the TRIzol (Invitrogen ${ }^{\circledR}$ ) reagent was performed according to \\ the manufacturer's instructions (https://assets.thermofisher.com/TFS- \\ Assets/LSG/manuals/trizol_reagent.pdf).
}

\section{DNase treatment and cDNA synthesis}

RNA samples $(5 \mu \mathrm{g})$ were treated with DNase I using the Turbo DNA-free kit (Ambion) for elimination of residual DNA contamination. RNA content, as well as quality $\left(\mathrm{A}_{260} / \mathrm{A}_{280}\right.$ and $\mathrm{A}_{260} / \mathrm{A}_{230}$ ) were accessed by spectroscopy (Nanodrop ${ }^{\circledR} \mathrm{ND}-1000$ ), and its integrity was visually analyzed in $1.0 \%$ agarose gel. Considering the difficulties found in isolating RNA from sweet potato tuberous roots, due to their high starch content, RNA integrity for this tissue was also evaluated with the Agilent 2100 Bioanalyzer.

One $\mu \mathrm{g}$ of the total RNA was reverse transcribed into cDNA using the High- Capacity cDNA Reverse Transcription Kit (Thermo Fisher Scientific, Waltham, USA), according to manufacturer's protocol, and subsequently stored at $-20{ }^{\circ} \mathrm{C}$.

\section{Primer design and Real-Time quantitative PCR (RT-qPCR)}


Gene expression analysis through RT-qPCR consisted in the evaluation of the expression profile of the gene IbSRDI (Storage Root Development-related 1), which was chosen due to its crucial role on sweet potato root development (Noh et al., 2010), on sweet potato tuberous roots, leaves, and branches, using the RNA obtained through the three extraction methods evaluated in this study. IbSRD1 primers were designed using the OligoPerfect software (https://apps.thermofisher.com/apps/oligoperfect/), and their quality was evaluated through the OligoAnalyzer tool (https://www.idtdna.com/calc/analyzer).

RT-qPCR analyses were carried out on a ABI PRISM 7500 fast Real-Time PCR thermalcycler (Applied Biosystems), using SYBR-green detection system and the cDNA obtained from the RNA extracted from the three sweet potato tissues and extraction methods. Reactions were carried out in $10 \mu \mathrm{L}$ reaction volume: $5 \mu \mathrm{L}$ of SYBR-green (Master Mix PowerUp SYBR green UDG with ROX) (Invitrogen), $0.2 \mu \mathrm{L}$ (0.2 M final concentration on the reaction) of forward and reverse gene-specific primers (see Table 1 for primer sequences and gene amplification efficiencies), $1 \mu \mathrm{L}$ of cDNA (80 ng), and $3.6 \mu \mathrm{L}$ of nuclease free water. Three biological replicates for each treatment were used, reactions were run in triplicates, and amplification was performed with the following reaction conditions: 2 min at $50{ }^{\circ} \mathrm{C}$, followed by 10 min at $95^{\circ} \mathrm{C}$, then 40 cycles $95^{\circ} \mathrm{C}$ for $15 \mathrm{~s}$ followed by 1 min at $60^{\circ} \mathrm{C}$, and completed with a melting curve analysis to access specificity of the reaction by raising the temperature from 60 to $95{ }^{\circ} \mathrm{C}$, with $1{ }^{\circ} \mathrm{C}$ increase in temperature every $5 \mathrm{~s}$. Relative fold differences were calculated based on the $\triangle \Delta C T$ method (Pfaffl, 2001), using IbAlfaTub (Alpha tubulin) e IbELF (translation initiation factor eIF-2B) as references genes (Yu et al., 2020), and were calculated relative to a calibrator sample (Biological replicate I from branch samples extracted through the hot acid phenol method).

Table 1. Gene names, GenBank accession numbers, RT-qPCR primer sequences, and gene amplification efficiencies of the analyzed genes from sweet potato.

\begin{tabular}{lllcc}
\hline \multicolumn{1}{c}{ Gene } & \multicolumn{1}{c}{$\begin{array}{c}\text { GenBank Accession } \\
\text { number }\end{array}$} & \multicolumn{1}{c}{ Primer sequence (5'-3') } & $\begin{array}{c}\text { Amplicon } \\
\mathbf{( p b )}\end{array}$ & $\begin{array}{c}\text { Amplification } \\
\text { efficiency } \mathbf{( \% )}\end{array}$ \\
\hline IbSRD1 & FJ237529.1 & $\begin{array}{l}\text { Fw: GCACAAGTGACCCAAATGC } \\
\text { Rv: GCTCTGGCTAGATCGCTG }\end{array}$ & 124 & 90 \\
$I b E L F$ & XM_019343175.1 & $\begin{array}{l}\text { Fw: ATCTCTTTGACGGCTGGTTG } \\
\text { Rv: CTCTGCACGCTCAAGAAGG }\end{array}$ & 111 & 98 \\
IbAlfaTub & BM878762.1 & $\begin{array}{l}\text { Fw: CAACCGGCTTCAAATGTGG } \\
\text { Rv: GTGGTCGATGCGTGAGAA }\end{array}$ & 137 & 100 \\
\hline
\end{tabular}

\section{RESULTS}

\section{RNA extraction methods}

The searches on the Web of Science and Scopus databases resulted in 12 studies that conducted RT-qPCR assays in sweet potato (Table S1). The analysis of the methodologies described in each paper allowed one to observe that two methods, TRIzol and commercial kits, comprised $54 \%$ and $46 \%$ of the studies, respectively (Figure 1). Thus, based on the results obtained from these databases, the TRIzol method was included in this study as a reference, since it is the method more commonly used for isolating RNA from sweet potato. The two other methods on the other hand, CTAB and Hot Acid Phenol, were chosen because they are often used in transcriptional studies in different organisms. 


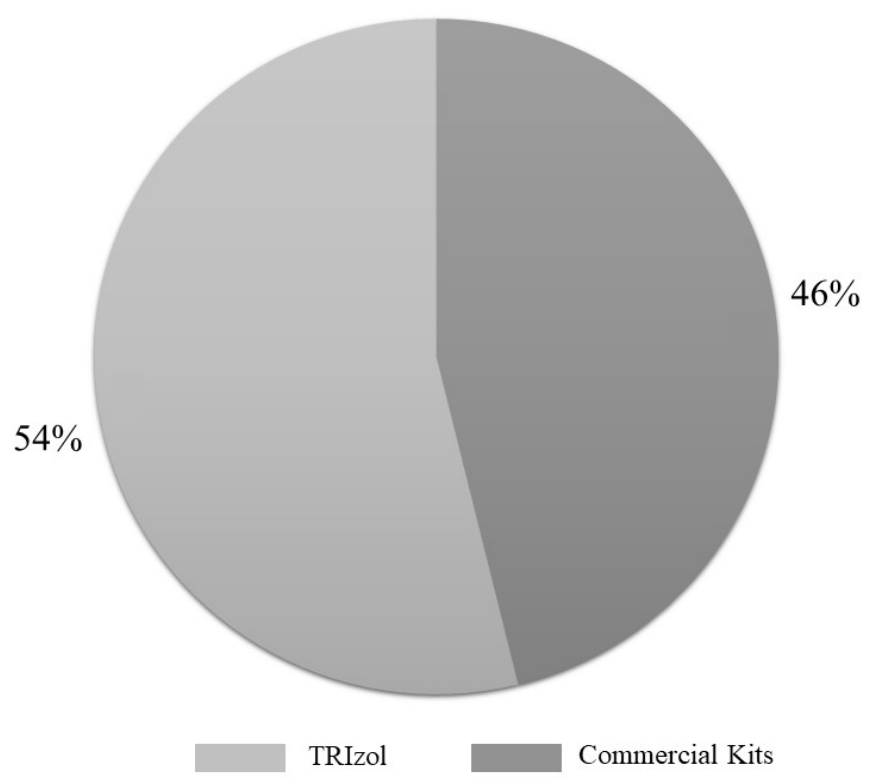

Figure 1. RNA isolation methods used in RT-qPCR studies conducted on sweet potato according to the Web of Science and Scopus databases.

\section{RNA quantity and purity}

The three RNA isolation methods analyzed here generated sufficient RNA for performing sensitive molecular studies (Table 2). Comparing the RNA quantities among each extracting method, one can observe that the hot acid phenol, the CTAB, and the TRIzol methods displayed mean values of $297.07 \mathrm{ng} / \mu \mathrm{L}$ to $730.73 \mathrm{ng} / \mu \mathrm{L}, 334.53 \mathrm{ng} / \mu \mathrm{L}$ to $608.77 \mathrm{ng} / \mu \mathrm{L}$, and $315.30 \mathrm{ng} / \mu \mathrm{L}$ to $518.23 \mathrm{ng} / \mu \mathrm{L}$, respectively (Table 2 ).

Table 2. Comparison of the RNA quantity and purity obtained from different sweet potato tissues through different RNA isolation methods.

\begin{tabular}{lllll}
\hline \multirow{2}{*}{ RNA extraction method } & Tissues & Quantity & Purity & Purity A260/A230 \\
& RNA (ng/ $\boldsymbol{\mu L})$ & $1.93 \pm 0.03$ & $2.23 \pm 0.01$ \\
\multirow{2}{*}{ Hot acid phenol } & Tuberous roots & $297.07 \pm 14.90$ & $1.92 \pm 0.01$ & $2.24 \pm 0.05$ \\
& Branches & $362.87 \pm 25.68$ & $2.00 \pm 0.03$ & $1.99 \pm 0.21$ \\
\hline \multirow{2}{*}{ CTAB* } & Leaves & $730.73 \pm 191.56$ & $2.16 \pm 0.01$ & $1.80 \pm 0.05$ \\
& Tuberous roots & $334.53 \pm 34.04$ & $2.10 \pm 0.01$ & $2.09 \pm 0.05$ \\
& Branches & $608.77 \pm 41.12$ & $2.07 \pm 0.06$ & $1.91 \pm 0.20$ \\
\hline \multirow{2}{*}{ TRIzol } & Leaves & $592.20 \pm 177.25$ & $1.96 \pm 0.01$ & $0.41 \pm 0.03$ \\
& Tuberous roots & $315.30 \pm 96.03$ & $2.04 \pm 0.04$ & $0.56 \pm 0.05$ \\
\end{tabular}

${ }^{*}$ CTAB (cethyltrimethylammonium bromide)

In relation to RNA purity, the analysis of the $\mathrm{A}_{260} / \mathrm{A}_{280}$ and $\mathrm{A}_{260} / \mathrm{A}_{230}$ ratios showed that the RNA isolated through the CTAB and hot acid phenol methods displayed values above 1.8 , indicating the high purity standards of these samples. On the other hand, for the 
TRIzol method, RNA from all tissues analyzed showed values below 1.0 for the $\mathrm{A}_{260} / \mathrm{A}_{230}$ ratio, indicating the contamination of the samples (Table 2).

\section{RNA integrity}

The analysis of RNA integrity through agarose gel allowed the clear visualization of the two ribosomal RNA subunits (28S and $18 \mathrm{~S}$ ) for the three RNA isolation procedures analyzed, except for the RNA (RNA partially degraded) from leaves (Biological replicate II - L2) extracted through the CTAB method and the TRIzol method (RNA completely degraded).
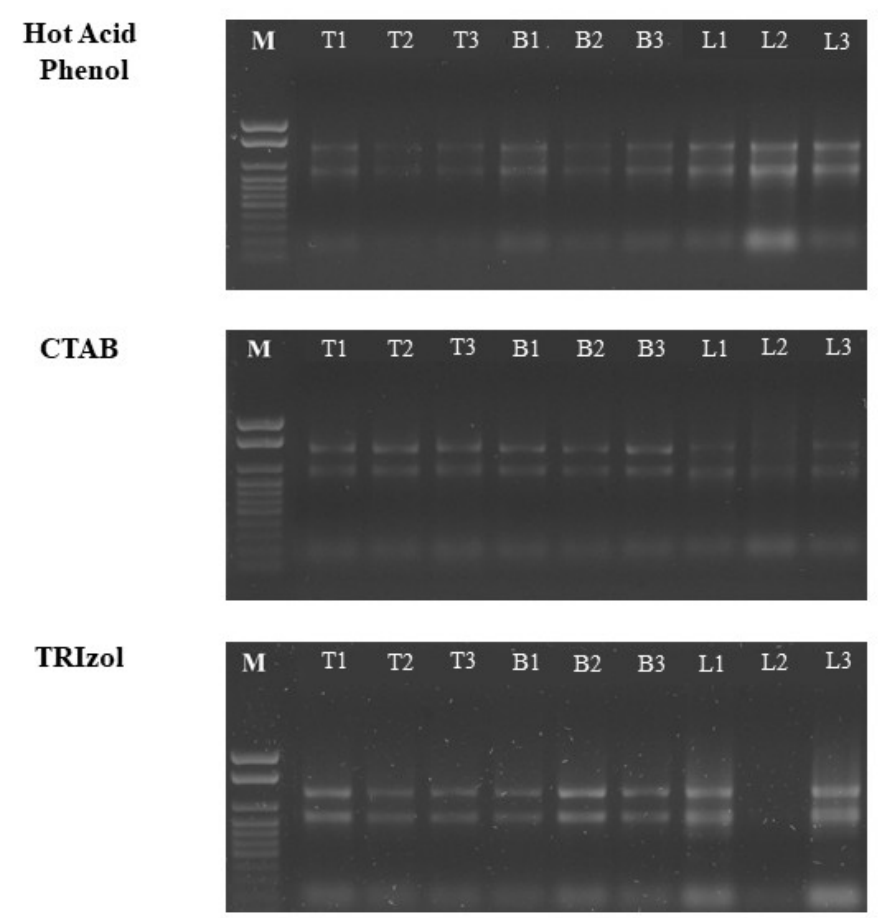

Figure 2. Integrity analysis of the RNA isolated from different sweet potato tissues (T: tuberous roots; S: stem; L: Leaves) through the hot acid phenol, CTAB, and TRIzol methods. Agarose gels (1.0\%) were stained with Sybr safe. $\mathrm{M}$ - $1 \mathrm{~Kb}$ molecular weight marker.

About the RIN (RNA Integrity Number) analysis, carried out on tuberous roots samples, it could be observed, for the three RNA isolation methods, good integrity levels, with RIN values above 6.5 (Figure 3), which is in accordance with the results from the integrity analysis through agarose gels. However, the analysis of the electropherograms generated from each biological replicate allowed the observation that the RNA samples obtained through the TRIzol method showed an elevated basal line (Figure 3), possibly a result of the contaminants related to the $\mathrm{A}_{260} / \mathrm{A}_{230}$ ratio, which showed values below 1.0 (Table 2).

\section{Gene expression analysis}

The analysis of the relative expression of the IbSDRI gene in the three sweet potato tissues, using the RNA obtained from the three different isolating methods tested in this study, 
showed that IbSDRI was more expressed in tuberous roots, except when the RNA was extracted through the TRIzol method (Figure 4). The relatively higher expression on tuberous roots was an expected result, considering that this gene is related with the development of tuberous roots in sweet potato. In relation to the low expression levels of IbSDRI when RNA was isolated through the TRIzol method, this result was possibly related to the contamination of the samples, as observed in Table 2 and the noise present through the entire electropherogram of these samples (Figure 3).

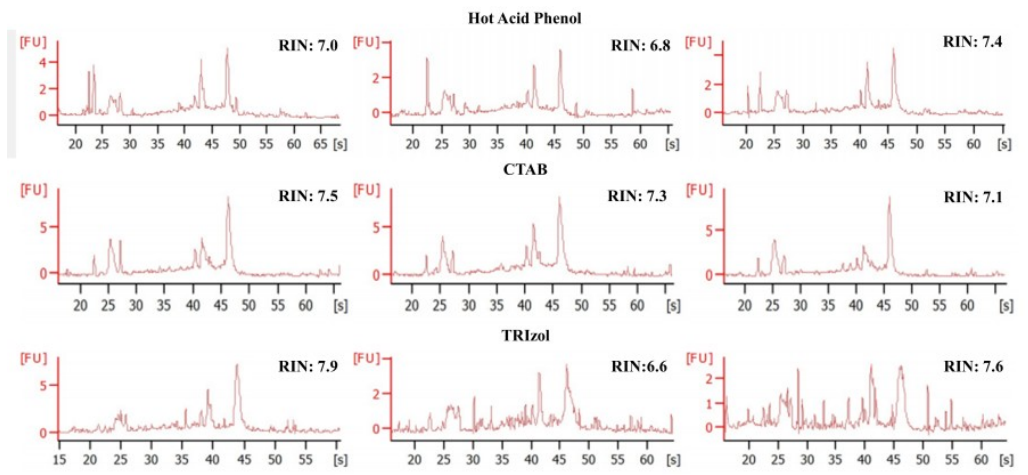

Figure 3. Electropherograms generated from the chip electrophoresis, performed with Bioanalyzer 2100, of the RNA samples isolated from sweet potato tuberous roots through the hot acid phenol, CTAB, and TRIzol methods.

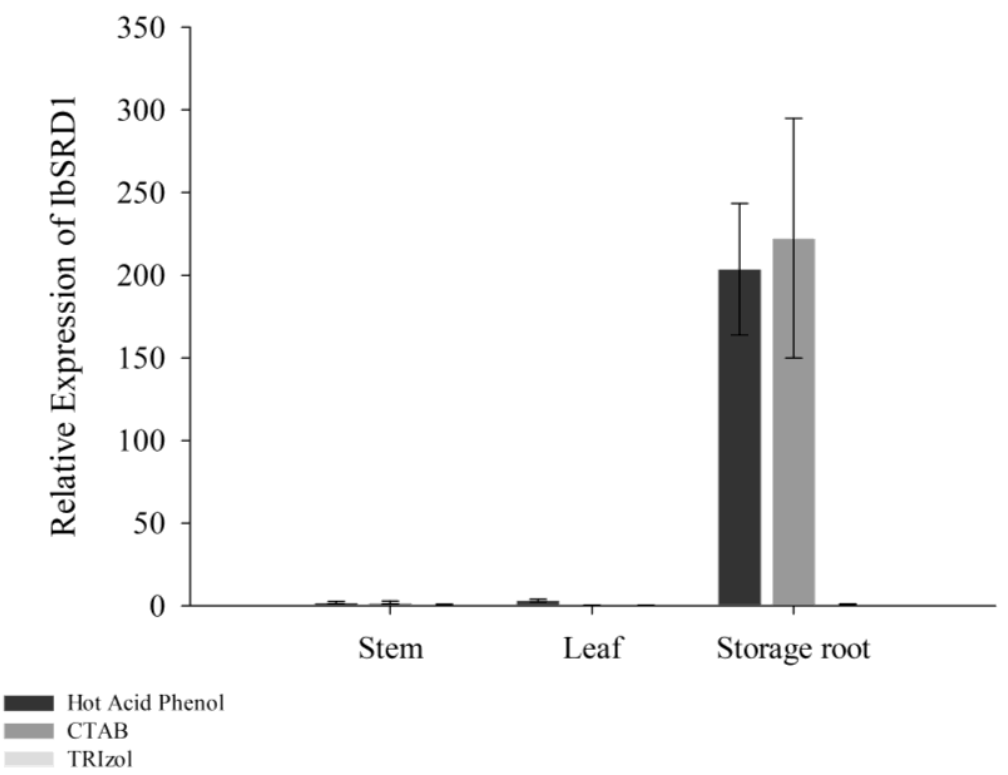

Figure 4. Relative quantitative expression profile of $I b S D R I$ in sweet potato stem, leaves, and tuberous root, using the RNA obtained from three different methods (hot phenol acid, CTAB, TRIzol). Columns represent the fold difference in gene expression among the different RNA extraction methods for each tissue, relative to a calibrator sample (Biological replicate I from branch samples extracted through the hot acid phenol method). The relative quantification was obtained by the formula $\mathrm{E}_{\text {target }} \Delta \mathrm{CTtarget} / \mathrm{E}_{\text {reference }} \Delta \mathrm{CTreference}$ (Pfaffl, 2001), using IbELF and $I b A l f a T u b$ as reference genes. Expression values for each biological sample were obtained from three biological repetitions and error bars represent the standard error for them. 


\section{DISCUSSION}

\section{RNA extraction methods}

In this study, the evaluation of three different RNA extraction methods, hot acid phenol, CTAB and TRIzol, for obtaining high-quality RNA from different tissues from sweet potato, showed that, although all of them generated RNA at sufficient quantities for molecular studies, the RNA obtained from TRIzol method displayed lower quality when compared to the other methods.

The three RNA isolation methods analyzed here showed that the hot acid phenol method has not been used so far in transcriptional studies of this species (Table S1), even though it is considered an efficient RNA extraction method that has been used in other organisms (Scholes and Lewis, 2020; De Souza et al., 2021). For the CTAB method, according to the search performed on the Web of Science and Scopus databases, this method also has not been used in transcriptional studies of sweet potato. However, studies that are not present on these databases, aiming the optimization of the RNA isolation method for obtaining high-quality RNA, have been carried out using this method in sweet potato (Suzuki et al., 2008; Zhou et al., 2009). However, these optimizations are related to macro-extractions, which requires more plant material and reagents. In relation to the TRIzol method, it was shown to be the most commonly used method for RNA isolation from sweet potato so far (Table S1). Park et al. (2017) and Meng et al. (2018), for instance, used this method to isolate RNA and evaluate the gene expression profile of High-affinity $K+$ transporter 1 (IbHKTl) (involved in salinity tolerance) and genes from the NAC family (involved in the response of several abiotic stresses), respectively, through RT-qPCR. Hou et al. (2021) used the TRIzol method to isolate RNA and analyze genes from the Bgalactosidase family, which are involved in the response of biotic and abiotic stresses. In addition, the TRIzol method has also been used on the transcriptome sequencing of sweet potato (Tao et al., 2012), and on the characterization of ERD15, a gene that seems to be involved in the defense response to water stress in sweet potato (Shao et al., 2014), to identify water deficit responsive genes in RNAseq and RT-qPCR studies (Arisha et al., 2020), in the validation of reference genes for the expression normalization of miRNAs (Liu et al., 2020), and for the evaluation of genes associated to starch and sucrose metabolism (Ma et al., 2020; Qin et al., 2021).

\section{RNA quantity and purity}

The challenge of extracting high-quality RNA is in part related to the need of preventing RNA contamination with polysaccharides and polyphenols, which can be found in different amounts according to the tissue and species and can bind to nucleic acids, affecting their quality and integrity (Behnam et al., 2019; Badai et al., 2020). Thus, these parameters were evaluated here to determine the most efficient method for isolating RNA from sweet potato.

An RNA quantity commonly used for DNase treatment in transcriptional studies using the RT-qPCR technique is $5 \mu \mathrm{g}$, with $1 \mu \mathrm{g}$ being then used for the cDNA synthesis (Freitas et al., 2019; Daude et al., 2020; De Souza et al., 2021), with these quantities varying according to the kits that are used. Thus, a concentration of at least $250 \mathrm{ng} / \mu \mathrm{g}$, in a 
$20 \mu \mathrm{L}$ volume (as used in this study), is required to perform the further analysis, and as one can observe in Table 2, all RNA isolation methods tested in this study generated sufficient RNA quantities to perform the gene expression analysis.

In relation to the purity of the samples, the absorbance at $230 \mathrm{~nm}, 260 \mathrm{~nm}$, and 280 $\mathrm{nm}$ are evaluated. The $\mathrm{A}_{260} / \mathrm{A}_{230}$ ratio indicates the contamination of the RNA sample with polysaccharides or polyphenols, and the $\mathrm{A}_{260} / \mathrm{A}_{280}$ ratio indicates the contamination with proteins (Liu et al., 2018). The analysis of the results generated here allowed the observation that the RNA from the three sweet potato tissues analyzed here generated satisfactory results towards the $\mathrm{A}_{260} / \mathrm{A}_{230}$ and $\mathrm{A}_{260} / \mathrm{A}_{280}$ ratios, except when the TRIzol method was used, where the $A_{260} / A_{230}$ ratio was significantly reduced in all tissues (Table 2).

One of the procedures that have helped in obtaining high-quality RNA for the hot acid phenol and CTAB methods was the use of the TES buffer (10 Mm de TRIS-HCL Ph 7,5, $10 \mathrm{mM}$ de EDTA e 0,5\% SDS). This buffer contains the reagent SDS (Sodium Dodecyl Sulfate), which according to Behnam et al., (2019), it is an anionic detergent that, in addition to solubilizing proteins and lipids, facilitates sample lysis. Different RNA extraction protocols have been optimized for the use of SDS, providing higher RNA quantities and elevated purity ratios (Behnam et al. 2019; Vennapusa et al., 2020).

For the CTAB method, in addition to using TES in the RNA extraction procedure, the RNA isolation uses chloroform for removing proteins, resulting in a colorless RNA and, through the use of $\mathrm{NaCl}(2 \mathrm{M})$ in the buffer, it is possible to remove polysaccharides (Chang et al., 1993). Thus, the CTAB method is commonly used for the RNA isolation from tissues with high polysaccharide contents (Ong et al., 2019; Qadri et al., 2019). However, it is a method not commonly used for RNA extraction from sweet potato tissues.

In relation to the TRIzol method, though it is widely used in transcriptional studies of sweet potato (Figure 1), the results found in this study were not satisfactory. Although this RNA extraction method has been used in other species (Acosta-Maspons et al., 2019; Behnam et al., 2019; Guan et al., 2019), the different optimizations present in these studies were not sufficient to improve the purity of RNA obtained.

\section{RNA integrity}

The RNA integrity can be evaluated through the use of agarose gels (Azizi et al., 2017; Murgan et al., 2020), as well as through the determination of the RIN (Siles et al., 2020; Vennapusa et al., 2020). However, the integrity analyzed by agarose gels depends on the interpretation of images by the user, which is prone to errors, differently the RIN approach, where an algorithm is used to standardize the RNA quality control, generating an integrity number (Schroeder et al., 2006).

The algorithm evaluates aspects such as: total RNA proportion (compares the fraction area of the $18 \mathrm{~S}$ and $28 \mathrm{~S}$ region with the total area), the $28 \mathrm{~S}$ peak height, and the ratio between the fast region and marker height. By analyzing these parameters, the RNA integrity is classified into ten different categories ( 1 to 10$)$, where an intact RNA receives a RIN of 10 and a totally degraded RNA displays a RIN of 1 (Schroeder et al., 2006). Fleige and Pfaffl (2006) consider RNA samples with good integrity levels for RT-qPCR studies those presenting RINs above 5. 
In the present study, we obtained $\mathrm{RIN} \geq 6.6$ for the RNA samples obtained through the three RNA isolation methods tested (Figure 3), what is similar to other studies present in the literature, such as transcriptional studies through qPCR from Coffea arabica (Freitas et al., 2017), Pelargonium zonale, and Ramonda serbica (Vidović and Ćuković, 2020), and Manihot esculenta (Behnam et al., 2019; Guan et al., 2019). For instance, in the study developed by Freitas et al. (2017), RINs $\geq 7.0$ were obtained for different tissues in an assay for the validation of reference genes for RT-qPCR analysis of Coffea arabica somatic embryogenesis-related tissues.

\section{RT-qPCR}

IbSDRI is a MADS-box gene that has an important role in storage roots (Noh et al., 2010). Considering this, the promoter region of this gene from sweet potato has been analyzed in Arabidopsis, carrot, and transgenic potato, aiming to direct the expression to storage organs (Noh et al., 2012). IbSDRl overexpression is able to double the number of sweet potato storage roots (Bae et al., 2013). In addition, IbSDRI seems to be involved in the regulation of the Indole-3-acetic acid concentration ( $\mathrm{Si}$ et al., 2018), which is an auxin essential root growth (Han et al., 2019).

The results described in the literature corroborates with the one obtained here when the RNA from sweet potato tissues was extracted through the hot acid phenol and CTAB methods, since IbSDRI showed relatively higher expression levels in tuberous roots and displayed a basal expression level in the other tissues (stem and leaves) (Figure 4). On the other hand, when RNA was isolated through the TRIzol method, the results showed that the RNA quality directly affected the reaction, inhibiting the PCR, similar to what has been reported in other studies, as observed by Huma et al. (2020). In this study, where different RNA isolation methods were tested in citrus, low values for the $\mathrm{A}_{260} / \mathrm{A}_{230}$ ratio directly affect the expression analysis, leading to the absence of amplification in the RT-PCR analysis.

\section{CONCLUSIONS}

The three RNA extraction methods tested here (hot acid phenol, CTAB and TRIzol) allowed the isolation of RNA with sufficient quantities for carrying out molecular studies in sweet potato. In relation to RNA quality, the hot acid phenol and CTAB methods generated satisfactory results for conducting transcriptional studies through RT-qPCR in sweet potato, while the TRIzol method must be optimized, since it can lead to imprecise results. To conclude, the hot acid phenol and CTAB methods, not commonly used for transcriptional studies in sweet potato so far, are excellent choices for the RNA extraction from different sweet potato tissues.

\section{ACKNOWLEDGMENTS}

We thank the "Conselho Nacional de Desenvolvimento Científico e Tecnológico CNPq - projeto Universal (Process number 433729/2018-0)", the "Coordenação de Aperfeiçoamento de Pessoal de Nível Superior (CAPES)", the "Rede de Biodiversidade e Biotecnologia da Amazônia Legal (Bionorte)", the "Programa de Mestrado em Agroenergia 
Digital da UFT (Agroenergia Digital-UFT)", the "Universidade Federal do Tocantins (PROPESQ-UFT)" and the "Fundação de Amparo à Pesquisa do Estado do Tocantins (FAPT)" for the financial support.

\title{
CONFLICTS OF INTEREST
}

\author{
The authors declare no conflict of interest.
}

\section{REFERENCES}

Acosta-Maspons A, González-Lemes I and Covarrubias AA (2019). Improved protocol for isolation of high-quality total RNA from different organs of Phaseolus vulgaris L. BioTechniques. 66: 96-98. DOI: 10.2144/btn-2018-0129.

Anwar A and Kim JK (2020). Transgenic breeding approaches for improving abiotic stress tolerance: recent progress and future perspectives. Int. J. Mol. Sci. 21: 2695. DOI: 10.3390/ijms21082695.

Arisha MH, Ahmad MQ, Tang W, Liu Y, et al. (2020). RNA-sequencing analysis revealed genes associated drought stress responses of different durations in hexaploid sweet potato. Sci. Rep. 10: 12573. DOI: 10.1038/s41598-02069232-3.

Azevedo AM, Andrade JVC, Viana DJ, Elsayed AY, et al. (2014). Influence of harvest time and cultivation sites on the productivity and quality of sweet potato. Hortic. Bras. 32: 21-27. DOI: 10.1590/S0102-05362014000100004.

Azizi P, Rafii MY, Mahmood M, Abdullah SNA, et al. (2017). Evaluation of RNA extraction methods in rice and their application in expression analysis of resistance genes against Magnaporthe oryzae. Biotechnol. Biotechnol. Equip. 31: 75-84. 1 DOI: 10.080/13102818.2016.1259015.

Bae JM, Shin JS, Noh SA and Paek KH (2013). Sweetpotato SRD1 cDNA and transgenic plants with high-numbered storage roots using the same. US Patent $8481816 \mathrm{~B} 2$. Date issued: 9 july.

Badai SS, Rasid OA, Parveez GKA and Masani MYA (2020). A rapid RNA extraction method from oil palm tissues suitable for reverse transcription quantitative real-time PCR (RT-qPCR). 3 Biotech. 10: 530. DOI: 10.1007/s13205020-02514-9.

Basso MF, Arraes FBM, Grossi-de-Sa M, Moreira VJV, et al. (2020). Insights Into Genetic and Molecular Elements for Transgenic Crop Development. Front. Plant Sci. 11: 509. DOI: 10.3389/fpls.2020.00509.

Behnam B, Bohorquez-Chaux A, Castaneda-Mendez OF, Tsuji H, et al. (2019). An optimized isolation protocol yields high-quality RNA from cassava tissues (Manihot esculenta Crantz). FEBS Open Bio. 9: 814-825. DOI: $10.1002 / 2211-5463.12561$.

Bustin SA, Benes V, Garson JA, Hellemans J, et al. (2009). The MIQE Guidelines: Minimum Information for Publication of Quantitative Real-Time PCR Experiments. Clin. Chem. 55: 611-622. DOI: 10.1373/clinchem.2008.112797.

Chang S, Puryear J and Cairney J (1993). A simple and efficient method for isolating RNA from pine trees. Plant Mol. Biol. Rep. 11: 113-116. DOI: 10.1007/BF02670468.

Daude MM, Silva TWDS, Freitas NC, Ságio SA, et al. (2020). Transcriptional analysis of WUSCHEL-related HOMEOBOX (WOX) genes in Coffea arabica L. Biologia. 75: 1483-1495. DOI: 10.2478/s11756-020-00460-8.

De Souza MR, Teixeira RC, Daude MM, Augusto ANL, et al. (2021). Comparative assessment of three RNA extraction methods for obtaining high-quality RNA from Candida viswanathii biomass. J. Microbiol. Methods. 184: 106200. DOI: 10.1016/j.mimet.2021.106200.

Derveaux S, Vandesompele J and Hellemans J (2010). How to do successful gene expression analysis using real-time PCR. Methods. 50: 227-230. DOI: 10.1016/j.ymeth.2009.11.001.

FAOSTAT (2021). Food and Agriculture Organization of the United Nations. http://www.fao.org/faostat/en/\#data/QC. Access 25 march 2021.

Fleige S and Pfaffl MW (2006). RNA integrity and the effect on the real-time qRT-PCR performance. Mol. Aspects Med. 27: 126-139. DOI: 10.1016/j.mam.2005.12.003.

Freitas NC, Barreto HG, Fernandes-Brum CN, Moreira RO, et al. (2017). Validation of reference genes for qPCR analysis of Coffea arabica L. somatic embryogenesis-related tissues. Plant Cell, Tissue Organ Cult. 128: 663-678. DOI: $10.1007 / \mathrm{s} 11240-016-1147-6$.

Freitas NC, Barreto HG, Torres LF, Freire LL, et al. (2019). In silico and in vivo analysis of ABI3 and VAL2 genes during somatic embryogenesis of Coffea arabica: competence acquisition and developmental marker genes. Plant Cell, Tissue Organ Cult. 137: 599-611. DOI: 10.1007/s11240-019-01594-7.

Guan L, Ma X, Zhou X, Tan B, et al. (2019). An optimized method to obtain high-quality RNA from cassava storage root. 3 Biotech. 9: 118. DOI: 10.1007/s13205-019-1608-9. 
Guo H, Kong F and Yan C (2017). Optimization of polysaccharide ultrasonic extraction conditions using purple sweet potato tubers based on free radical scavenging and glycosylation inhibitory bioactivities. Pharmacogn. Mag. 13: 504-511. DOI: 10.4103/0973-1296.211044.

GuoLiang L, Guochun X, Zhaomiao L, Huawei L, et al. (2020). Selection of suitable reference genes for RT-qPCR normalisation in sweet potato (Ipomoea batatas L.) under different stresses. J. Hortic. Sci. Biotechnol. 96: 209-219. DOI: $10.1080 / 14620316.2020 .1829502$.

Han S, Jia MZ, Yang JF and Jiang J (2019). The integration of ACS2-generated ACC with GH3-mediated IAA homeostasis in NaCl-stressed primary root elongation of Arabidopsis seedlings. Plant Growth Regul. 88: 151-158. DOI: $10.1007 / \mathrm{s} 10725-019-00495-1$.

Hou F, Du T, Qin Z, Xu T, et al. (2021). Genome-wide in silico identification and expression analysis of betagalactosidase family members in sweetpotato [Ipomoea batatas (L.) Lam]. BMC Genom. 22: 140. DOI: 10.1186/s12864-021-07436-1.

Huded AKC, Jingade P and Mishra MK (2018). A rapid and efficient SDS-based RNA isolation protocol from different tissues of coffee. 3 Biotech. 8: 183. DOI: 10.1007/s13205-018-1209-z.

Huma N, Sahar S, Iftikhar Y, Azhar A, et al. (2020). RNA isolation efficacy of commercial and modified conventional methods for Citrus tristeza virus and mRNA internal control amplification. Biologia. 75: 1195-1202. DOI: 10.2478/s11756-019-00405-w.

IBGE (2019). Produção Agrícola Municipal. Sistema IBGE de Recuperação Automática - SIDRA. Available from: https://www.spo.cnptia.embrapa.br/conteudo?p_p_id=conteudoportlet_WAR_sistemasdeproducao]. Accessed 05 September 2021

Liu L, Han R, Yu N, Zhang W, et al. (2018). A method for extracting high-quality total RNA from plant rich in polysaccharides and polyphenols using Dendrobium huoshanense. PLoS One. 13: e0196592. DOI: 10.1371/journal.pone.0196592.

Liu X, Liu S, Zhang J, Wu Y, et al. (2020). Optimization of reference genes for qRT-PCR analysis of microRNA expression under abiotic stress conditions in sweetpotato. Plant Physiol. Biochem. 154:379-386. DOI: 10.1016/j.plaphy.2020.06.016.

Ma H, Li C, Yang S and Zhang Y (2020). Glutamate promotes sweet potato storage root swelling by enhancing starch accumulation. Acta Physiol. Plant. 42: 58. DOI: 10.1007/s11738-020-3029-0.

MAPA (2019). Ministério da Agricultura, Pecuária e Abastecimento. Registro Nacional de Cultivares - RNC. Available in: [http://sistemas.agricultura.gov.br/snpc/

cultivarweb/cultivares_registradas.php]. Access 10 August 2021.

Meng X, Li G, Yu J, Cai J, et al. (2018). Isolation, Expression Analysis, and Function Evaluation of 12 Novel Stress-Responsive Genes of NAC Transcription Factors in Sweetpotato. Crop Sci. 58: 1328-1341. DOI: 10.2135/cropsci2017.12.0738.

Murgan OK, Kazakova AD and Efimova MV (2020). Comparison of methods for RNA extraction from potato plants for real-time PCR. Tomsk State University Journal of Biology. 51: 123-140. DOI: 10.17223/19988591/51/7.

Noh SA, Lee HS, Huh GH, Oh MJ, et al. (2012). A sweetpotato SRD1 promoter confers strong root-, taproot-, and tuberspecific expression in Arabidopsis, carrot, and potato. Transgenic Res. 21: 265-278. DOI: 10.1007/s11248-0119528-4.

Noh SA, Lee HS, Huh EJ, Huh GH, et al. (2010). SRD1 is involved in the auxin-mediated initial thickening growth of storage root by enhancing proliferation of metaxylem and cambium cells in sweetpotato (Ipomoea batatas). J. Exp. Bot. 61: 1337-1349. DOI: 10.1093/jxb/erp399.

Ong PW, Chan PL, Ooi LCL and Singh R (2019). Isolation of high quality total RNA from various tissues of oil palm (Elaeis guineensis) for reverse transcription quantitative real-time PCR (RT-qPCR). J. Oil Palm Res. 31: 195-203. DOI: 10.21894/jopr.2019.0014.

Park SC, Yu YC, Kou M, Yan H, et al. (2017). Ipomoea batatas HKT1 transporter homolog mediates $\mathrm{K}+$ and $\mathrm{Na}^{+}$ uptake in Saccharomyces cerevisiae. J. Integr. Agric. 16: 2168-2176. DOI: 10.1016/S2095-3119(16)61570-8.

Paula MFBD, Ságio SA, Lazzari F, Barreto HG, et al. (2012). Efficiency of RNA extraction protocols in different types of coffee plant tissues. Coffee http://www.coffeescience.ufla.br/index.php/Coffeescience/article/view/385. Accessed on: 30 aug. 2021.

Pfaffl MW (2001). A new mathematical model for relative quantification in real-time RT-PCR. Nucleic Acids Res. 29: e45. DOI: 10.1093/nar/29.9.e45.

Pessu PO, Abel GI, Akande SA, Ayanda IS, et al. (2020). Chemical and physico-chemical properties of orange fleshed sweet potatoes (OFSP) chips dried using solar dyers. Agrosearch. 20: 144-157. DOI: 10.4314/agrosh.v20i1.13S.

Qadri R, Iqbal A, Wu Y, Li J, et al. (2019). A modified protocol for total RNA isolation from different oil palm (Elaeis guineensis) tissues using cetyltrimethylammonium bromide. Curr. Sci. 116: 479-482. DOI: $10.18520 / \mathrm{cs} / \mathrm{v} 116 / \mathrm{i} 3 / 479-482$.

Qin Z, Li A, Dong S, Wang Q, et al. (2021). Comparative Transcriptome Analysis of Hybrid Population Provides Insights Into Starch Content in Sweet Potato (Ipomoea batatas L.) Storage Root. Plant Mol. Biol. Rep. DOI: 10.1007/s11105-021-01282-x. 
Rizzolo JA, Woiciechowski AL, Júnior AIM, Torres LAZ, et al. (2021). The potential of sweet potato biorefinery and development of alternative uses. SN Appl. Sci. 3: 347. DOI: 10.1007/s42452-021-04369-y.

Schroeder A, Mueller O, Stocker S, Salowsky R, et al. (2006). The RIN: an RNA integrity number for assigning integrity values to RNA measurements. BMC Mol. Biol. 7: 3. DOI: 10.1186/1471-2199-7-3.

Scholes AN and Lewis JA (2020). Comparison of RNA isolation methods on RNA-Seq: implications for differential expression and meta-analyses. BMC Genom. 21: 249. DOI: 10.1186/s12864-020-6673-2.

Shao HH, Chen SD, Zhang K, Cao QH, et al. (2014). Isolation and expression studies of the ERD15 gene involved in drought-stressed responses. Genet. Mol. Res. 13: 10852-10862. DOI: 10.4238 / 2014.Dezembro.19.6.

Si C, Shi C, Liu H, Zhan X, et al. (2018). Influence of two nitrogen forms on hormone metabolism in potential storage roots and storage root number of sweetpotato. Crop Sci. 58: 2558-2568. DOI: 10.2135/cropsci2018.01.0067.

Siles L, Eastmond P and Kurup S (2020). Big data from small tissues: extraction of high-quality RNA for RNAsequencing from different oilseed Brassica seed tissues during seed development. Plant Methods. 16: 80. DOI: 10.1101/2019.12.20.885012.

Srisuwan S, Sihachakr D and Siljak-Yakovlev S (2006). The origin and evolution of sweet potato (Ipomoea batatas Lam.) and its wild relatives through the cytogenetic approaches. Plant Sci. 171: 424-433. DOI: 10.1016/j.plantsci.2006.05.007.

Suzuki Y, Mae T and Makino A (2008). RNA extraction from various recalcitrant plant tissues with a cethyltrimethylammonium bromide-containing buffer followed by a acid guanidium thiocyanate-phenol-chloroform treatment. Biosci. Biotechnol. Biochem. 72: 1951-1953. DOI: 10.1271/bbb.80084.

Tao X, Gu YH, Wang HY, Zheng W, et al. (2012). Digital gene expression analysis based on integrated de novo transcriptome assembly of sweet potato [Ipomoea batatas (L.) Lam.]. PloS One. 7: e36234. DOI: 10.1371/journal.pone.0036234.

Vennapusa AR, Somayanda IM, Doherty CJ and Jagadish SK (2020). A universal method for high-quality RNA extraction from plant tissues rich in starch, proteins and fiber. Sci. Rep. 10: 16887. DOI: 10.1038/s41598-02073958-5.

Vidović M and Ćuković K (2020). Isolation of high-quality RNA from recalcitrant leaves of variegated and resurrection plants. 3 Biotech. 10: 286. DOI: 10.1007/s13205-020-02279-1.

Wang A, Li R, Ren L, Gao X, et al. (2018). A comparative metabolomics study of flavonoids in sweet potato with different flesh colors (Ipomoea batatas (L.) Lam). Food Chem. 260: 124-134. DOI: 10.1016/j.foodchem.2018.03.125.

Yu J, Su Y, Sun J, Liu J, et al. (2020). Selection of stable reference genes for gene expression analysis in sweet potato (Ipomoea batatas L.). Mol. Cell. Probes. 53: 101610. DOI: 10.1016/j.mcp.2020.101610.

Zhang ZC, Wang HB, Zhou Q, Hu B, et al. (2017). Screening of effective xanthine oxidase inhibitors in dietary anthocyanins from purple sweet potato (Ipomoea batatas L. Cultivar Eshu No. 8) and deciphering of the underlying mechanisms in vitro. J. Funct. Foods. 36: 102-111. DOI: 10.1016/j.jff.2017.06.048.

Zhou W, Gong Y, Feng Q and Gao F (2009). An improved method of isolation of high quality total RNA from purplefleshed sweet potato, Ipomoea batatas (L.) Lam. Prep. Biochem. Biotechnol. 39: 95-104. DOI: $10.1080 / 10826060902800122$ 